\title{
MATISSE E A RELIGIÃO DA ARTE
}

\section{Paola Lins de Oliveira ${ }^{1}$}

(D) https://orcid.org/0000-0002-7104-5842

${ }^{1}$ Universidade Estadual do Rio de Janeiro (UERJ), Rio de Janeiro - RJ, Brasil.

E-mail: paolalins@gmail.com

DOI: $10.1590 / 3510407 / 2020$

\section{Introdução ${ }^{1}$}

O objetivo deste artigo é analisar as relaçóes entre o artista plástico francês Henri Matisse (1869-1954) e a religião a partir da edificação da Capela de Nossa Senhora do Rosário, idealizada e construída por ele e colaboradores na cidade de Vence, sul da França, entre os anos de 1947 e 1951 . Até aquele momento, Matisse nunca havia assumido publicamente qualquer adesão religiosa. Além disso, ao longo de sua trajetória, desenvolveu seu trabalho ancorado nas temáticas da ornamentação, do prazer, da felicidade, da volúpia do corpo feminino. O projeto de Vence aturdiu tanto artistas quanto religiosos, suscitando um debate sobre os limites entre a produção de uma arte de vanguarda e suas possibilidades de diálogo ou associação com a religião.

Artigo recebido em: 13/03/2019

Aprovado em: 06/02/2020
Grande parte do debate em torno de experiências artístico-religiosas desde o final do século XIX se concentrou nas incongruências da parceria baseada no paradigma moderno da secularização e da separação entre as esferas da vida social (Weber, 1982; Asad, 2003). O processo de construção da Capela de Vence ilumina as sobreposições entre arte e religião, enfocando as continuidades entre as instâncias sociais, orquestradas por Matisse e todos os atores envolvidos em sua elaboração, cujas relaçóes ultrapassam as clivagens modernas supostamente dadas (Latour, 1994). A discussão provocada pelo projeto, as reaçóes dos seus interlocutores, jornalistas, artistas, críticos de arte e religiosos explicitam as expectativas de preservação dessas fronteiras, contribuindo para criá-las (Latour, 2005), assim como para formar o espaço secular (Asad, 2003). Nesse plano, o caso da capela concebida por Matisse contribui para a reflexão sobre as relaçóes entre religião e outro "campo" ou "esfera" da vida social que não apenas a "política", 
enfoque privilegiado nas pesquisas sobre a formação do secular no Brasil (Giumbelli, 2002; Montero, 2016; Ranquetat, 2014).

É preciso assinalar que o empreendimento e sua repercussão se inscrevem em um contexto histórico de experimentos conduzidos por arquitetos e artistas envolvidos na criação de espaços, ornamentos e objetos litúrgicos católicos ancorados na agenda estética moderna, os quais analisei em outra ocasião (Oliveira, 2014). Esse movimento de modernização da arte sacra, como denominaram Gamboni (1997) e Baptista (2002), encontrou muita resistência por parte da hierarquia católica, abertamente preocupada com as consequências das parcerias com artistas e arquitetos não cristãos e com a adoção de uma estética moderna na produção e decoração dos seus templos. Muito embora a maior parte das experiências tenha ocorrido na Europa, há casos no Brasil, sendo um dos mais emblemáticos o da Igreja de São Francisco de Assis, localizada no Complexo Arquitetônico da Pampulha (Belo Horizonte, Minas Gerais), projetada por Oscar Niemeyer e decorada por Cândido Portinari, entre outros artistas. A Igrejinha da Pampulha, como ficou conhecida, permaneceu fechada durante quatorze anos diante da recusa do arcebispo da cidade em consagrar uma capela que mais parecia um "museu de arte moderna" do que uma "casa de Deus" (Oliveira, 2018). ${ }^{2}$

No contexto reflexivo amparado no paradigma da compartimentação das esferas, a relação entre religião e arte vem sendo explorada por trabalhos que mostram o papel da sacralização no processo de autonomização do campo artístico (Heinich, 2005; Reinheimer, 2008), e o modo como este último se apropriou de termos e procedimentos do primeiro. Essas pesquisas são muito importantes para escrutinar a institucionalização da arte, e seus efeitos estruturais. Entretanto, minhas reflexões não estão nessa linha. Neste artigo, analiso o modo como Matisse transita entre as dimensões da arte e da religião para além do imperativo de institucionalização de sua obra. Meu interesse recai sobre o modo como o artista se apropria de temas, práticas, experiências religiosas como potência criativa para a elaboração do seu trabalho, e simultaneamente para a modulação da sua pessoa. Ao longo da análise, recupero outros trabalhos e momentos da produção de Matisse explicitando um procedimento mais geral e recorrente de espiritualização da sua obra e de si mesmo.

As reflexôes que aqui apresento são resultado da minha pesquisa de doutorado, realizada no Brasil e na França, e que contou com trabalho de campo em Vence e em Paris, ${ }^{3}$ levantando material sobre a idealização e a construção da capela do Rosário. ${ }^{4}$

A seguir, passo à análise das relaçôes entre arte e religião na obra de Matisse desenvolvida em cinco partes. Na primeira seção, apresento a Capela do Rosário de Vence como projeto de construção de uma obra de arte total, assim como as reaçóes negativas que provocou em artistas, críticos de arte e jornalistas. A segunda seção traz uma introdução da metodologia de criação artística de Matisse fundamentada nos procedimentos de imersão, mergulho na interioridade e experiência, identificando seus pontos de contato com o surgimento de uma forma moderna de sensibilidade, herdeira da noção de pessoa cristá. Mais do que um tema de trabalho em Vence, a religião ou o sagrado emergem como modo de experimentar sua arte e também sua vida, tópico examinado na terceira seção sob o eixo central do artista como médium, "receptáculo" da força criadora. A interação entre o artista-médium e as forças que o ocupam são exploradas a partir da ideia do transe, que altera seus níveis de consciência e percepção de si. Na quarta seção, estabeleço alguns pontos de contato entre o transe artístico de Matisse e o jogo evidenciando o modo como o artista utiliza tal combinação como recurso criativo para alcançar o efeito de "espiritualização" que pretende. Nesse processo, a materialização de alguns elementos figurativos como a máscara e a face operam como gatilhos da sacralização da Capela. Na quinta seção, retorno às reações dos seus interlocutores, detendo-me às expectativas secularizantes direcionadas ao papel da religião e da arte na Capela do Rosário e na vida social.

Ao final do percurso, espero ter tornado mais inteligíveis os contornos do consórcio entre arte e religião materializados na Capela do Rosário de Vence, e ter iluminado o modo como tal parceria tensiona o paradigma secular e moderno da separação entre as instâncias da vida social. 


\section{Matisse e a capela como obra de arte total}

Encravada em uma encosta da cidade medieval francesa de Vence, a Capela de Nossa Senhora do Rosário é inaugurada em junho de 1951 em uma cerimônia que ilustra a enorme repercussão que provoca nos meios artístico e religioso, impacto reversamente proporcional às suas singelas dimensões. Seus 90 metros quadrados decorados com três painéis de traços negros sobre cerâmica branca e dois jogos de vitrais em verde, azul e amarelo, ilustrados nas Figuras 1 e 2, recebem naquela manhã de verão uma profusão de visitantes.

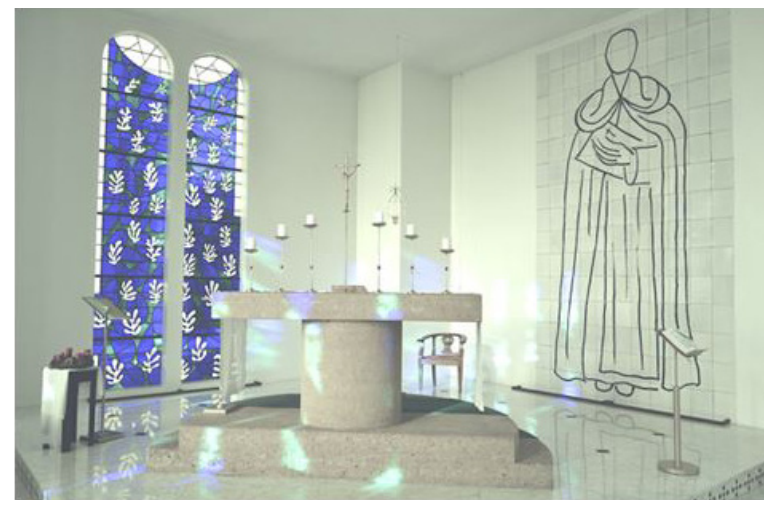

Figura 1: Santuário com altar, duplo vitral e painel de São Domingos. Acervo pessoal.

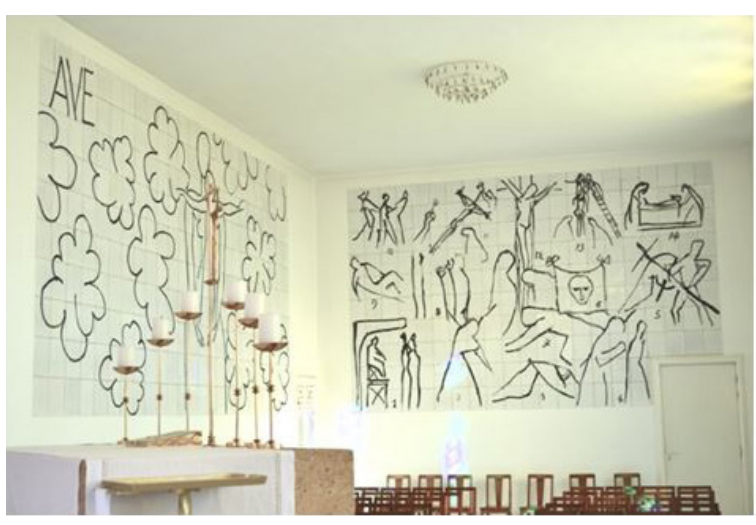

Figura 2: Nave com painel da Virgem com o Menino Jesus e a Via-crúcis. Acervo pessoal.
Com a capela lotada, muitas pessoas ficam do lado de fora, aproveitando a transmissão do evento realizada pela imprensa ${ }^{5}$. A presença de personalidades do mundo artístico, da política local, da hierarquia religiosa e de curiosos atesta o interesse plural em torno daquela experiência artística e religiosa. Depois de muitos anos dedicados exclusivamente aos circuitos artísticos, a empreitada religiosa realizada por Matisse, em colaboração com o frade dominicano Rayssiguier, provoca surpresa.

Natural do norte do país, Matisse trilhava seus primeiros passos como assistente de advocacia quando uma longa convalescença o coloca em contato com a paixão de sua mãe, pintora amadora. Meses depois, aos vinte e dois anos, se matricula numa academia de pintura contra a vontade do pai comerciante. Através da técnica acadêmica e do treinamento para a realização de cópias no Museu do Louvre, em Paris, o artista desenvolve um estilo inicial em sintonia com os cânones estabelecidos da pintura, sendo bem aceito no Salão Nacional de Belas Artes (1896). À medida que Matisse entra em contato com artistas impressionistas e se distancia dos postulados realistas que regiam a pintura acadêmica, seu trabalho passa a ser cada vez menos celebrado nos círculos de arte tradicionais e mais incorporado aos salóes e exposições independentes. Mesmo nesses ambientes, sua obra recebe frequentes críticas em relação ao seu traço simplificado (demais, para alguns), à sua paleta de cores, aos temas escolhidos: corpos femininos, ambientes domésticos e seus objetos, janelas que emolduram paisagens ensolaradas. Chega a receber o título ambíguo de "fauve", ou selvagem, de um crítico aturdido com suas pinceladas densas e cores vivas. ${ }^{6}$ Nome que passa a ser usado para designar uma escola, a qual Matisse lideraria, mas que aos poucos deixa de ser associada ao artista, cada vez mais reconhecido pela particularidade da sua obra. Em mais de sessenta anos de trabalho, Matisse sobreviveu a três guerras, ${ }^{7}$ a vários problemas de saúde, viajou pelo mundo para $\operatorname{pintar}^{8}$ e explorou diferentes técnicas além da pintura, passando pela escultura, gravura, litogravura até os guaches recortados do fim da vida, entre outras. Até os últimos anos de sua longa trajetória não abordou explicitamente o tema da religião. No fim da década de 1940, quando assume publicamente o 
projeto de construir e decorar uma capela católica por iniciativa própria, a partir da proximidade com a freira Jacques-Marie, ${ }^{9}$ muitas reaçōes emergem a respeito da (ausência de) religiosidade do artista.

Matisse inicia o projeto da capela aos 78 anos. Em entrevista ao professor de ciências humanas Georges Charbonnier (12/1/1951), ele afirma que há muito tempo pretendia "sintetizar" sua contribuição e que esta se apresentara entáo como a ocasião (apud Matisse, 2007). Para ele, tratava-se de uma oportunidade única para realizar uma obra de arte total: uma composição de espaços, murais, vitrais e objetos que iam do portal do confessionário passando pelo aparato litúrgico e até mesmo as vestimentas sacerdotais. A ideia, porém, de que Matisse pretendesse epitomizar sua arte com um objeto religioso provocara mal-estar entre seus amigos e admiradores, desconfiados da sua associação com o catolicismo.

Após a inauguração da Capela, em 1952, André Verdet, poeta, pintor e escultor, escreve ao artista: "Com a realizaçáo da capela de Vence, dizem, entre outras coisas, que você se reaproximou da religiâo católica”. Ao que Matisse responde:

Dizem e escrevem muitas coisas. Fazem circular montes de histórias, na Europa e nos Estados Unidos. A obra de arte náo passava de um pretexto para histórias. Em primeiro lugar, a arte sagrada requer boa higiene moral. Minha única religião é a do amor pela obra a criar, o amor pela criação e pela grande sinceridade. Fiz essa capela com o unico sentimento de me exprimir a fundo. (apud Matisse, 2007, p. 310-311, grifos meus)

Ao falar de boa higiene moral e simultaneamente declarar sua independência religiosa, defendendo a religiāo do amor à arte, o artista procura tranquilizar religiosos e artistas quanto às suas intenções e a sua capacidade (moral e artística) de realizar tal projeto.

Em outra passagem da entrevista mencionada, Charbonnier quer saber de Matisse: "Você acha - sei que minha pergunta vai soar um pouco canhestra - que existe uma arte religiosa?", ao que o artista responde:

Toda arte digna desse nome é religiosa. Por exemplo, uma criação feita de linhas, de cores: se essa criação não é religiosa, ela não existe. Se essa criação não é religiosa, não passa de arte documental, de arte episódica [...] que não é mais arte. Que não tem nada a ver com arte [...] (apud Matisse, 2007, p. 314)

A perspectiva expressa na pergunta de Charbonnier, muito semelhante à dos críticos religiosos, traduz a corrente principal da crítica de arte do século $\mathrm{XX}$, que confinou a religião a um "lugar estranho", deslocado, pouco respeitado ou mesmo ignorado dentro da produção da arte de vanguarda (Elkins, 2004). ${ }^{10}$ Retomo este ponto mais adiante.

A resistência à ideia de que o pintor da felicidade, do hedonismo, da voluptuosidade das cores e do corpo feminino trate de uma temática religiosa, entre seus pares, ganha ares de animosidade direta. Françoise Gilot, artista plástica e companheira de Picasso, teria presenciado um diálogo no qual, de um lado, o pintor espanhol instiga: "mas por que você faz aquelas coisas? Eu concordaria se você fosse católico. Caso contrário, acho que você não tem o direito moral"; a que o artista francês, seu amigo pessoal, responde:

Pra mim, tudo aquilo é essencialmente uma obra de arte. Eu medito e me compenetro do que vou fazer. Não sei se tenho fé ou não. Talvez eu seja mais budista. O essencial é trabalhar num estado de espirito próximo da prece". (Gilot apud Matisse, 2007 , p. 316, grifos meus)

Picasso ressaltava a incoerência entre o trabalho artístico de Matisse até aquele momento e seu engajamento em um projeto ligado a uma instituição que, do ponto de vista do primeiro, representava a antítese da obra deste último. Já Matisse era ambíguo. Sua fala revela dúvidas quanto a uma adesão estritamente religiosa ou uma postura antirreligiosa, ao mesmo tempo que reconhecia a importância de um componente "espiritual” para a realização do seu trabalho.

Em seguida, passo à análise de procedimentos e disposições adotados pelo artista na elaboração da sua obra, em Vence e em outras criaçóes, que se articulam a uma dimensão espiritual, religiosa ou sagrada. 
Imersão, interioridade, disciplina e sacerdócio

O método da imersão no tema é um procedimento constante na obra de Matisse. Em um conjunto de anotaçôes sobre sua técnica de desenho, o artista desmonta a crítica à suposta facilidade dos seus traços detalhando os inúmeros estudos que realiza com carvão ou esfuminho, antes do desenho final. Esse é o procedimento

[...] que permite avaliar simultaneamente o caráter do modelo, sua expressão humana, a qualidade da luz que o cerca, seu ambiente e tudo o que só o desenho permite exprimir. E somente quando tenho a sensação de estar esgotado por esse trabalho, o qual pode durar várias sessóes, é que, com o espírito aclarado, posso deixar fluir a pena com confiança. (revista Le Point 1939 apud Matisse, 2007, pp. 177-178)

Matisse conduz o exercício de linhas capturando diversas dimensóes do modelo no ambiente até esgotá-las em si mesmo. Nesse momento, a impressão dessas linhas em seu espírito o clarifica para que seja capaz de produzir finalmente o desenho. Em outra ocasião, Matisse perguntará ao poeta Aragon:

um desenho não será a síntese, o final de uma série de sensaçóes que o cérebro reteve, reuniu, e que é desencadeado por uma última sensação, de maneira que executo o desenho com a irresponsabilidade de um médium? (apud Matisse, 2007, p. 178)

Esse ponto fica ainda mais claro em um texto sobre retratos publicado pelo artista em 1954, quando ele explicita sua técnica de produção envolvendo uma relação específica com o modelo a ser representado: "depois de limpar, esvaziar meu cérebro de qualquer ideia preconcebida, eu traçava essa indicação preliminar com a mão submetida exclusivamente às minhas sensaçóes inconscientes, nascidas do modelo" (Matisse, 2007, pp. 198-199). Nesse processo, as impressōes do modelo repercutem no artista como ondas imediatas de sensaçôes de modo que ele finalmente afirma: "Senti-me tomado pelas revelaçôes de minha caneta e entendi que o espírito que compóe deve manter uma espécie de virgindade diante dos elementos escolhidos e rejeitar o que the vem pelo raciocínio" (p. 198).

Soares (1979), entre outros autores, tem identificado o empréstimo de alegorias religiosas feito por artistas para refletir e explicar suas produçóes. Ele destaca que alguns elementos são compartilhados entre as instâncias da arte e da religião, sobretudo os "indicadores da percepçẫo das práticas artísticas e religiosas enquanto resultados de um desdobramento do sujeito, ou melhor, de uma certa relação entre o individual e o supraindividual" (Soares, 1979, p. 124). Tal desdobramento ocorreria frequentemente através de um mergulho no inconsciente ou do contato com uma alteridade, por vezes considerada sagrada e capaz de ocupar o artista, transformando-o em médium.

A analogia com a figura do médium, enquanto canalizador de impressóes, formas, elementos externos, ganha contornos místicos quando Matisse se envolve na produção da Capela do Rosário. No discurso proferido à ocasião da inauguraçáo do Museu Henri Matisse, em novembro de 1952, o artista faz um balanço de sua vida e obra, concluindo que

[...] é na criação da Capela de Vence que eu enfim despertei para mim mesmo e compreendi que todo o trabalho encarniçado da minha vida era para a grande família humana, à qual deveria ser revelada um pouco da fresca beleza do mundo por meu intermédio. Eu nada fui além de um médium (Matisse, 2005, p. 320).

Alguns anos antes, Matisse já enfrentava essas questôes. Em resposta à carta da irmã Jacques-Marie, onde se lia "o Senhor nos disse: "Fora da minha Igreja não há salvaçâo"', ele escreve no verão de 1945:

Minha trajetória não foi exatamente assim. Eu fui conduzido (muito modestamente) entretanto, e só o constatei nesses últimos anos retornando ao meu caminho, a me considerar como tendo, na terra, sido designado pelo Altíssimo para refrescar no espírito dos outros homens a visão das coisas que levam a uma elevação do espírito que conduz ao Criador. Eu obedeço, eu creio firmemente nisso, ao Pai, ao Filho e ao Espírito 
Santo. Minha contemplação não pode ser simplesmente admiradora, mas deve ser ativa, pôr em movimento todos os recursos do espírito para criar o meio o mais direto para elevar o espírito dos meus semelhantes em direção a uma região que os retira das suas baixas condiçóes humanas. [...] Você reza por mim. Obrigado. Peça a Deus para me dar nos meus últimos anos a clareza de espírito que me porá em contato com ele; que me permitirá conduzir minha carreira longa e laboriosa em direção ao que eu sempre procurei: tornar sua glória evidente aos cegos por alimentos exclusivamente terrestres. [...] Eis aqui, cara Irmã Jacques-Marie, minha profissão de fé provocada por sua carta. (apud Jacques-Marie, 1992, p. 165)

Ao tomar para si a tarefa grandiosa de revelar a beleza do mundo para a humanidade ou refrescar nos homens a visão das coisas que elevam o espírito ao Criador, Matisse apresenta uma leitura sagrada do seu papel como veículo para efetivar tal revelação.

O mergulho no tema também reflete a busca por uma dimensão não evidente e imediata. O que o artista chama de "verdade essencial"; algo que transcende o que a aparência exata oferece aos olhos. No texto "A exatidão não é a verdade", Matisse afirma:

[...] cada um desses desenhos, a meu ver, traz uma invenção que lhe é própria e provém da penetração do tema pelo artista, que chega a se identificar plenamente com ele, de modo que a verdade essencial em questão é o que constitui o desenho. [...] a expressão dessa verdade por meio da maleabilidade e da liberdade de sua linha se dobra às exigências da composição; ela se matiza, e até se vivifica, com o feitio espiritual do artista que a imprime. A exatidão não é a verdade. (Prefácio do catálogo da Exposição "Matisse, desenhos” de 1947 apud Matisse, 2007, p. 195)

A imersão permite acessar a "verdade essencial" do tema, mas ela sozinha não produz a obra: é preciso ainda contar com a liberdade do gesto, as demandas da composição e o "feitio espiritual do artista". Esses movimentos - voltados para uma dimensão de "interioridade" e de "experiência" - que compóem a "metodologia artística" de Matisse, estão diretamente relacionados ao repertório constitutivo da noção moderna de pessoa forjada a partir de sua base cristá.

De acordo com Dias Duarte e Giumbelli (1995, p. 105), a introspecçâo em busca de uma "verdade na interioridade" emerge no cristianismo pré-medieval, consolidando-se, no período pós-Reforma, nas teorias em torno da "absoluta singularidade do espírito individual”. Em sua fundaçáo se desenvolveu o ideário do "cuidado de si", amplamente adotado por cristãos como "modo de vida" voltado para a busca da independência do mundo exterior com práticas de autodisciplina, tais como exercícios espirituais, abstinência, entre outras. A vida monástica se torna seu auge: com o isolamento do mundo - de suas tentações e pecados -, os monges encontravam refúgio em um contramundo, no qual podiam se dedicar à purificação do corpo e consequente elevação da alma.

Também para Matisse o isolamento e a disciplina corporal são estratégias para uma imersão eficaz no tema, combinada ao mergulho na sua interioridade. Spurling (2012), biógrafa do artista, ressalta seu apego a uma rotina de trabalho intensa e a predileção por cidades e ateliês relativamente isolados dos centros mais movimentados. Ela menciona uma conversa com Lydia Delectorskaya, na qual a secretária particular de Matisse teria afirmado que, no cotidiano do artista, "tudo era feito em função de sua obra":

Ele se alimentava frugalmente a fim de não ter problemas digestivos, fazia sesta de modo a iniciar descansado uma nova sessão de trabalho [e] contratou uma enfermeira noturna na expectativa de desfrutar da maior quantidade possível de horas de sono. (Spurling, 2012, p. 501)

Há disposiçôes estritamente religiosas no ascetismo do artista. Segundo o frei Rayssiguier, Matisse lhe contara em fevereiro de 1949 que desenvolvera o hábito de ler a obra "Imitação de Cristo", ${ }^{11}$ o que complementa com a conclusão: "mas é difícil seguir tudo" (Spurling, 2012, p. 154). A dificuldade aqui revela no mínimo o esforço do artista em tentar “imitar o Cristo". A referência à obra aparece já na publicação Jazz, de 1947, onde Matisse reproduz um trecho exortando o amor: "um bem enorme, o único 
que torna leve o que é pesado e suporta com igual ânimo o que é desigual. Pois ele carrega o peso sem que seja um fardo e torna doce e agradável tudo o que é amargo" (Matisse, 2010, p. 30). Esses fragmentos surgem depois de uma passagem em que o artista responde à pergunta "Se eu acredito em Deus?":

Sim, quando eu trabalho. Quando eu sou submisso e modesto, eu me sinto profundamente auxiliado por alguém que me leva a fazer coisas que me ultrapassam. Entretanto, eu não sinto nenhum reconhecimento em relação a ele, pois é como se eu estivesse diante de um prestidigitador cujas artimanhas eu não consigo penetrar. Eu me sinto então frustrado do benefício da experiência que deveria ser a recompensa do meu esforço. Eu sou ingrato sem remorsos. (Matisse, 2010, p. 30)

Matisse conhece e tenta pôr em prática "exercícios espirituais" de imitação da vida de Jesus Cristo e, simultaneamente, afirma crer em Deus (exclusivamente) nos momentos de trabalho quando, ao adotar a postura (propícia) de submissão e modéstia, sente-se conduzido misteriosamente a trilhar certos caminhos formais que o transcendem. Retomo este ponto mais adiante quando tratar da composição da via-crúcis. Esse Deus, entretanto, não evoca no artista o sentimento de reverência e reconhecimento, pois seu modo de operação, semelhante a um truque de mágica, soa ininteligível e, consequentemente, desvinculado da possibilidade de apreensão da experiência. Note-se aqui uma diferença de tom adotada por Matisse entre a "profissão de fé" feita à irmã Jacques-Marie e esta passagem de Jazz. A ambiguidade é um traço marcante e recorrente do discurso do artista a respeito da sua adesão religiosa e será retomado mais adiante.

De todo modo, a aparente incoerência entre se dedicar a uma prática rigorosamente cristã e não aderir claramente a essa religião estaria, de acordo com Dias Duarte e Giumbelli (1995, p. 102), em sintonia com a herança legada pelos "pietismos pré-reformados, como o da Imitação de Cristo", ${ }^{12}$ que "atinge aí seu apogeu, com a abolição ou redução das mediaçóes institucionais historicamente sedimentadas na Igreja”. Ou seja, o estímulo às buscas espirituais interiorizadas por exercícios como o da imitação de Cristo inaugurou a possibilidade de desfrutar de experiências sagradas não mediadas pela Igreja - experiências-chave para todo o movimento de individualização do "espírito" posteriormente laicizado no período pós-Reforma.

Dias Duarte e Giumbelli (1995, p. 105) sublinham a existência de conexóes claras entre esses pietismos alemães (dos exercícios espirituais) e a emergência do romantismo, principalmente com a "máxima exploração da 'sensibilidade"”. A valorização da sensibilidade eleva a experiência do esforço pessoal ao status de objetivo em si mesmo. Um novo cenário se descortina: "a religiosidade é já agora porém toda interior: a arte, a Grande Arte do século XIX, será o templo do culto à criação individual, a nova fonte permanente de verdade" (p. 105). Ou seja, a religiáo se interioriza e a arte se torna a religião do autocultivo (Asad, 1993).

Em outro texto, Dias Duarte (1999) analisará o papel das emoçóes e sentimentos na cultura ocidental moderna a partir da ideia do "dispositivo de sensibilidade". Este nasce do "dispositivo de sexualidade" foucaultiano, para tentar dar conta, por sua vez, do conjunto de práticas discursivas e não discursivas que produziriam modos de sentir e agir. O "dispositivo de sensibilidade" se fundamenta em três aspectos: o ideal de perfectibilidade, baseado no entendimento de que "a espécie humana é dotada de uma capacidade de se aperfeiçoar indefinidamente" (Dias Duarte, 1999, p. 24); a valorização da experiência, enquanto contato dos sujeitos com o mundo; e a teoria do fisicalismo que considera a "corporalidade em si como dimensão autoexplicativa do humano" (p. 25).

Há sintonias entre esses aspectos e a obra de Matisse. Do ponto de vista da perfectibilidade, destaque-se o esforço do artista de desenvolver sua obra por meio da prática, da repetição até a exaustão. Em seu caso, perfectibilidade opera como sinônimo de depuração formal e não de perfeição realista. O fisicalismo aflora no interesse do artista pela expressão da figura humana e da sensualidade do corpo feminino. Esse ponto inclusive reforça o argumento de alguns críticos da iniciativa de Matisse em Vence, sejam eles religiosos, artistas, críticos de arte ou jornalistas. Em uma entrevista, Joseph Barry pergunta diretamente ao artista o que muitos comentários deixavam supor nas entrelinhas: "por que Matisse, o fauve da arte francesa, famoso por seus nus e odaliscas brilhantes, 
por Alegria de Viver, está conduzindo o que pode ser seu último grande esforço em direção à arte religiosa?" (The New York Times, dez. 1948), sugerindo uma espécie de arrependimento pelo paganismo de sua obra. Em reação, Matisse protesta: "à minha maneira, sempre cantei a glória de Deus e das suas criaçóes. Não mudei” (Barry, 1948, p. 310).

A experiência é o aspecto mais desenvolvido e valorizado em sua obra. É através dela que o artista se impregna dos temas pesquisados e, ao mesmo tempo, expressa seu sentimento, estabelecendo uma continuidade entre sua vida e arte. Além da impregnação, do isolamento, dos exercícios espirituais e da disciplina corporal, que envolvem o artista em uma atmosfera suspensa, essa continuidade também se expressa no ambiente físico. Isso porque Matisse também abolia as fronteiras entre seu espaço de vida e de trabalho, fazendo da sua casa, e frequentemente do seu quarto, seu ateliê, chegando a trabalhar, em períodos de doença ou convalescência, deitado em sua cama.

Esse embaralhamento entre vida e obra fica evidente na transformação por que passa sua casa-ateliê durante o período de elaboraçáo da Capela do Rosário. Assim, em fevereiro de 1950, o artista escreve ao padre Couturier mencionando uma visita inesperada de Picasso, sobre a qual afirma: "ele estava bem incomodado na minha casa, pois náo podia encontrar um ponto para lançar seus olhos que não tivesse algo relativo à capela" (Matisse et al., 1993, p. 298).

Além de transformar sua casa numa extensão da Capela, Matisse se apropriava da Capela como uma extensão da sua casa, o que aparece em uma conversa relatada por frei Rayssiguier, na qual o artista teria dito:

- Eu ainda vou dormir na igreja, vocês váo ver.

- Isso acontecerá com você mais do que a um monge, e você terá pensado mais do que muitos deles no problema de uma Igreja.

- Mas eu faço isso como eu faria uma coisa pagá.

- Sem dúvida, mas isso não impede que o problema seja o de uma igreja.

(Matisse et al., 1993, p. 129)
Enquanto o frei Rayssiguier reconhece no artista o interesse no "problema de uma igreja" mais profundo do que o que encontraria em um monge, Matisse afirma seu compromisso com a imersão independente da relaçấo com o objeto religioso. Trata-se, portanto, de trabalhar num estado de espírito próximo da prece, seja ela budista, cristã ou pagã.

\section{Mediunidade, transe, descontrole e instabilidade de si}

Em um estado meditativo ampliado, Matisse pode ser tanto o monge quanto o "velho mago", expressão adotada por sua biógrafa para designar o período compreendendo o final da vida do artista:

Matisse, que afirmou que todo desenho ou pintura era uma parte dele mesmo, parecia, nessa última década de vida, ter transfigurado até o ambiente físico em uma extensão de sua maneira própria de ver. Em termos tanto literais como metafísicos, ele estava atuando nas margens da percepção. 'Estou exaurido pelo fato de ter flertado por tanto tempo, e de modo mais ou menos ininterrupto, com essas cores encantadas', escreveu a Rouveyre no fim de 1943 (Spurling, 2012, pp. 497-498).

Matisse estava cada vez mais consciente desse seu movimento de imersão em um ambiente encantado, decorrente da manipulação mística de temas, técnicas e materiais, como se apreende de sua carta ao bispo de Nice, Monsenhor Rémond, no mesmo ano de inauguraçâo da Capela.

Comecei pelo profano, e eis que no findar de minha vida, muito naturalmente, termino pelo divino. Durante minha carreira, batalhei, combati forças que pareciam querer me deter. Um dia, encontrei-me diante da saída táo desejada. Não fui eu quem a descobriu, quem percebeu meu estado de alma; parece-me que foi um ideal que se impôs a mim. (Spurling, 2012, p. 310)

Diferentemente do que dissera sobre seu trabalho ter sido uma contínua exaltação da glória divina, 
nessa passagem, ele desenha um novo itinerário no qual sua vida passa por um processo de sacralização simultaneamente ativa e involuntária. A ideia de uma força externa e superior lhe impondo um ideal fica mais evidente em uma conversa na qual, segundo padre Couturier, Matisse teria reagido à sua afirmação de que deveria se orgulhar do seu trabalho na Capela com o seguinte comentário:

[...] estou contente, mas eu nunca fiquei orgulhoso do que fiz. Toda vez que eu tinha feito tudo o que podia com meus dez dedos, alguma coisa vinha terminar, algo que não dependia de mim, que vinha de outro lugar. É preciso fazer tudo o que se pode, e no momento em que está tudo terminado alguma influência celeste vem finalizar. (Matisse et al., 1993, p. 398)

Nas conversas entre Matisse e o padre Couturier, a ambiguidade de uma "influência celeste" é intercalada com um vocabulário mais claramente cristão, com referências diretas a Deus, tal como em outras duas ocasióes em que o religioso anota em seu diário passagens em que o artista defende ser guiado por uma força divina: primeiro em junho de 1948, quando teria dito "é sempre Deus que segura minha mão; não sou responsável” (Matisse et al., 1993, p. 66); e depois em junho de 1949, "Creio num Deus que me domina e me força a andar em tal direção" (p. 208).

É possível identificar pontes entre esses fragmentos e a ideia de inspiração artística como "contágio", elaborada por Soares (1979, pp. 123-124). Nesse sentido, o artista como sujeito da criação se percebe tomado por algo que lhe é exterior, de tal forma que "a mão que escreve de algum modo é conduzida. [...] Estar inspirado seria inflar-se de matéria estranha à natureza individual do sujeito. Este excesso, não o autor-em-si, transbordaria, tornando-se êmulo da criação".

A inspiração por "contágio" adquire feições mais ambíguas a partir da referência indireta a uma espécie de transe enquanto performance, na qual a divindade se apodera do corpo do iniciado e o conduz a agir em determinado sentido. Expressão análoga se manifesta em uma digressão sobre a relação entre poesia e religiáo feita pela poeta Adélia Prado em uma entrevista concedida a Ubiratan Brasil (2013), em $O$ Estado de S. Paulo, em 6 dezembro. Nela, Adélia afirma:

É simples, rigorosamente ninguém é o criador da Beleza (poesia). Ela vem, eu diria como Guimarães Rosa, da terceira margem da alma. O poeta é só o "cavalo do santo", queira ou não. Às vezes, somos tentados a desistir quando descobrimos que ela, a poesia, é muito melhor que seu autor. É a tentação do orgulho. Que Deus nos livre dela. (Brasil, 2013)

No candomblé, "cavalo do santo" designa o filho-de-santo que é possuído pelo orixá. Não apenas no candomblé, mas, nas religióes de matrizes africanas e afro-brasileiras, o fenômeno da possessão se conecta a uma alteraçấo nos níveis de consciência da pessoa incorporada e das entidades que a ocupam. Mudanças nas direçóes das análises sobre o fenômeno estão se deslocando de uma percepção funcionalista ou estritamente simbolista e se orientando para uma percepção do "corpo sensível” (Stoller, 1997). Esse percurso tem permitido complementar uma visão da possessão como possibilidade de "experimentação ativa de distintos estilos de apresentação de si" (Rabelo, 2008, p. 95) com o entendimento dos constrangimentos que ela impóe, sendo o espírito que sacraliza e apoia potencialmente um fardo (Birman, 2005), ao obrigar seu cavalo a lhe ceder seu corpo. No mesmo sentido dessa "experiência de sujeição" (Rabelo, 2008), Matisse narra sua relação com o deus dominador e condutor do seu trabalho.

De acordo com Goldman (1984), a prática da possessão está diretamente ligada à constituição da noção de pessoa nessa religião. Isso porque, diferentemente da lógica cristá da divindade unificada - que inspira a noção de pessoa cristã unificada -, no candomblé, a divindade é vista como "uma força natural cósmica, compost[a] de uma infinidade de planos, ou 'qualidades', hierarquicamente ordenados" (Goldman, 1984, p. 161) e a pessoa é compreendida como uma entidade "'folheada' e múltipla, composta por 'almas e duplos'” (p. 175), cuja constituição depende diretamente da confirmação através do complexo sistema ritual da possessão. Para Goldman, os sucessivos "assentamentos" dos santos que compóem 
a pessoa são acompanhados "por um acréscimo, 'em extensão', do transe, ou seja, adquire-se o direito (e mesmo o dever) de incorporar cada nova entidade assentada” (pp. 173-174). Náo somente os santos compóem a cabeça do filho-de-santo, mas a ocupam de tempos em tempos.

Nas religiōes de matrizes africanas, o caráter mais ou menos violento da sujeição da pessoa incorporada se relaciona ao seu nível de engajamento com a entidade; a dedicação total à vida religiosa sendo a postura mais propícia a neutralizá-la. A entrega e o tempo de experiência da possessão alteram não apenas a relação entre entidade e pessoa religiosa, mas a própria concepção de pessoa em jogo. Para Goldman (1984, p. 174), há, com o tempo, uma "diminuição no ritmo e na constância do êxtase - quanto mais 'velho no santo', menos um fiel deve ser possuído, até que no final do processo de construção de seu ser, com vinte e um anos de feito, o transe cesse totalmente de atingi-lo".

A analogia entre a mediunidade artística e o transe religioso parece encontrar aqui uma clivagem, pois, se no candomblé, “quanto mais 'estável' o equilíbrio da pessoa - pela incorporaçáo sucessiva de seus componentes -, menos a divindade deve tomá-la" Goldman (1984, pp. 173-174), a aproximação do final de sua vida propicia a Matisse entrar em contato cada vez mais frequente com as forças místicas que o conduzem a produzir sua obra. Talvez esteja em questão uma instabilidade permanente da pessoa, a busca como objetivo, que não conduz necessariamente à descoberta total de si. De toda forma, é por meio do contínuo estímulo à experiência do atravessamento (transe) que o artista permanece conectado à força criadora. Assim, mesmo "assujeitado", seria provavelmente mais prolífico pensar em uma ascendente emulação para a conexão com a divindade, em sentido semelhante a um desafio deliberado ou jogo a ser constantemente atualizado.

\section{Jogos, máscaras e desdobramento da consciência}

Em sua teoria dos jogos, Caillois (1990) estabelece uma divisão entre quatro tipos que privilegiam a competição, a sorte, a imitação e a vertigem. Sobre os jogos deste último tipo, ilinx, o autor afirma serem
[...] aqueles que [se] assentam na busca da vertigem e que consistem numa tentativa de destruir, por um instante, a estabilidade da percepção e infligir à consciência lúcida uma espécie de voluptuoso pânico. Em todos os casos, trata-se de atingir uma espécie de espasmo, de transe ou de estonteamento que desvanece a realidade com uma imensa brusquidão. (Caillois, 1990, p. 43)

Pensar o transe artístico de Matisse como jogo ajuda a sublinhar seu caráter voluntário, operado pelo acionamento de procedimentos propiciatórios, tais como, no caso do artista - assim como no do jogo -, a repetição.

Segundo Caillois, um elemento potencializador para os jogos de vertigem é a máscara. Ela emerge nos jogos de tipo mimicry, relacionados à imitação, à invenção e à representação, à criação artística. A máscara faz parte de um jogo de simulação, promovendo, para Caillois (1990, p. 97),

[...] uma espécie de desdobramento da consciência do ator entre a sua própria pessoa e o papel que desempenha. [...] Fingir que se é um outro aliena e extasia. Usar uma máscara embriaga e liberta. De maneira que, neste perigoso domínio onde a percepção vacila, a combinação da máscara e do transe é de todas a mais temível. Provoca um entusiasmo tal, atinge tais paroxismos que o mundo real fica provisoriamente suspenso na alucinada consciência do indivíduo possesso.

Está em evidência aqui o poder da máscara de produzir uma abertura, um desdobramento da consciência da pessoa que a porta. Combinada à vertigem do transe, seu efeito é o incremento do êxtase a um ponto perigoso de suspensão da realidade. Essa suspensão ganha um contorno singular, já que, segundo Caillois (1990, p. 97), "a simbiose da simulação e da vertigem é tão poderosa, tão irremediável que se insere naturalmente na esfera do sagrado e fornece provavelmente um dos principais impulsos para a mistura de terror e fascínio que define esse nível do sagrado". 
A máscara assim como o rosto emergem como meios de evocação de uma espiritualidade em outros trabalhos de Matisse. Para a conservadora do Museu Matisse em Nice, Marie-Thérèse Séligny (2003), a postura espiritual do artista ganha indubitável relevo ao longo do trabalho na Capela do Rosário, mas também no desenvolvimento de uma série de desenhos de rostos de "esquimós"13 realizados no mesmo período e destinados à publicação "Une fête em Cimmérie". Para ela, nesse trabalho, Matisse apura uma "reflexão e uma pesquisa gráfica sobre a representação do rosto humano" (Séligny, 2003, p. 29), dialogando com a representaçâo da espiritualidade a ser evocada na face da Virgem, de São Domingos e de Cristo na via-crúcis. É o que há de humano aglutinado na imagem do rosto que une as temáticas dos inuítes e dos santos da Capela do Rosário, pois, como pontua Séligny, Matisse dissera ainda em 1908, "o que mais me interessa não é nem a natureza-morta nem a paisagem, é a figura. É ela que me permite exprimir melhor o sentimento religioso, por assim dizer, que tenho da vida" (p. 47).

De maneira análoga, Le Breton sublinha a atmosfera sagrada que envolve o rosto humano. Segundo ele, esta "hierofania difusa" decorre da ambivalência que condensa no rosto "os valores mais altos: matriz de identificação onde brilha o sentimento de identidade, onde se fixam a sedução, as nuances inomináveis da beleza e da feiura" (Le Breton, 1995, p. 5) e cujo risco da "perda (desfiguração) priva frequentemente de toda razão de viver" justamente por fissurar "profundamente o sentimento de identidade" (p. 2). Esse movimento de atração e repulsão que provoca o rosto depende do modo como seus traços se conformam a ou se distanciam de padrōes de normalidade e integridade acionados por quem o olha. Sua sacralidade emerge de um trabalho de "distinçâo de minúcias", como defende Michel Leiris, dentro de um campo quase ilimitado de possibilidades.

O rosto é, antes de tudo, significado, refletindo de forma animada e enigmática o absoluto de uma diferença individual ainda que ínfima.
[...] Ele é a abertura infinitesimal pela qual cada homem se identifica. Os rostos são variaçốes ao infinito sobre uma mesma tela simples. (Leiris apud Le Breton, 1995, p. 4)

Parece ser essa a trilha percorrida por Matisse ao explorar as potencialidades plásticas do rosto em inúmeros retratos e autorretratos com uso de uma técnica composta da "reduçấo das linhas até a estilizaçáo apurada da máscara - 'sinal' representativo da essência do ser" (Séligny, 2003, p. 29). É justamente no conjunto de desenhos sobre os inuítes e sobre os santos da Capela do Rosário que o artista experimenta essa técnica para a condensação dos elementos da expressão, do olhar, da personalidade em uma identidade-síntese da humanidade, ou seja, àquela materializada na máscara, o que se apreende por exemplo do conjunto das figuras 3, 4 e 5 .

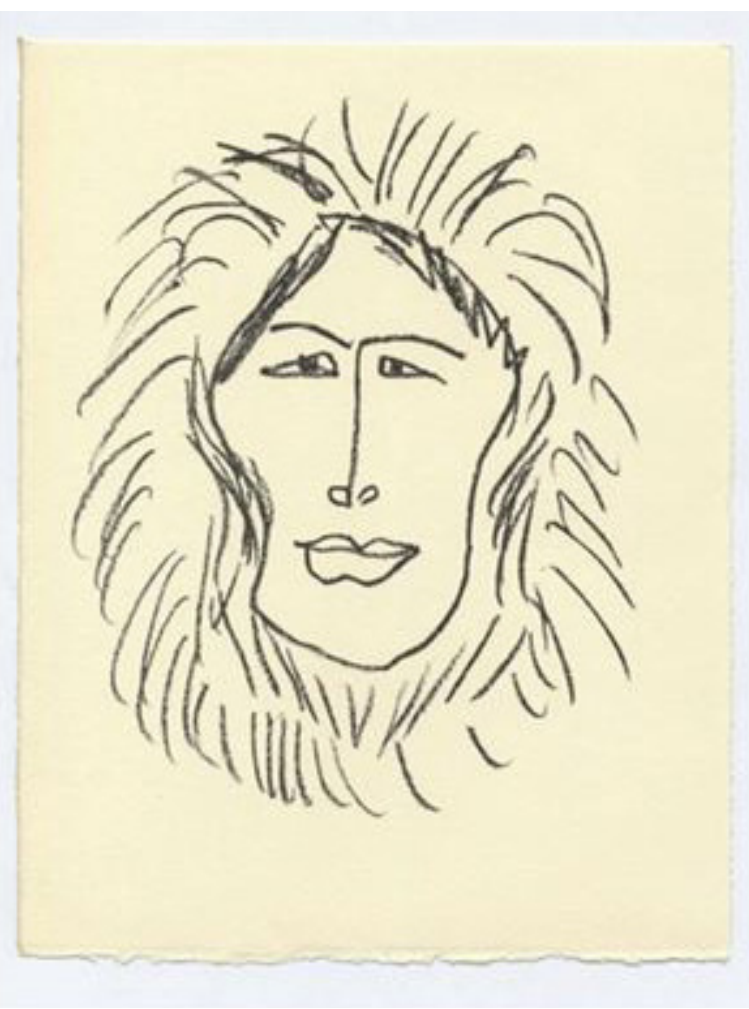

Figura 3: Une fête en Cimmérie. Prancha I (s.d.). Reproduçáo do catálogo da exposição de Matisse (Séligny, 2003, p. 10). 


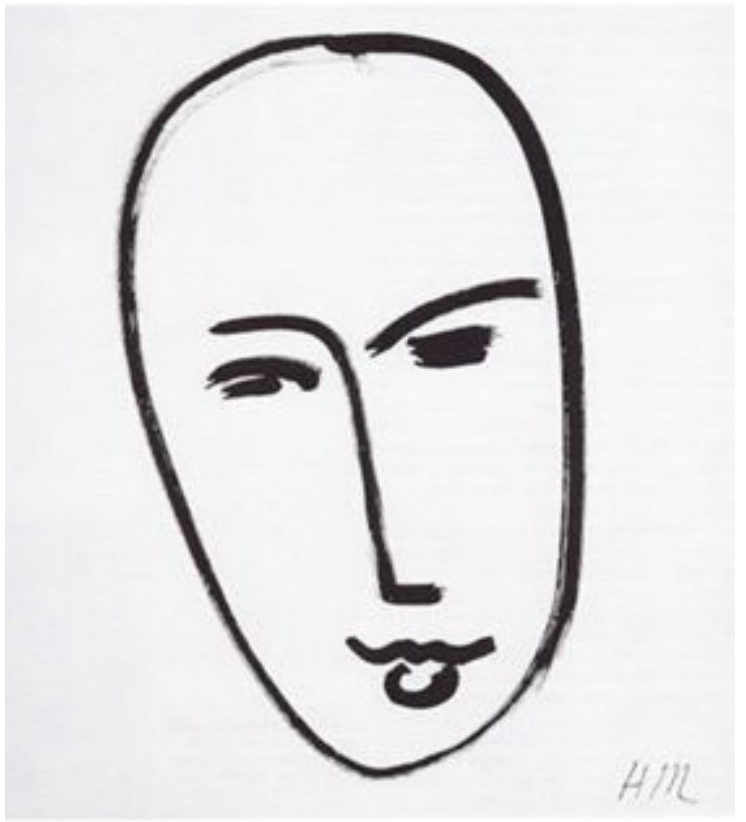

Figura 4: Cabeça grande (Máscara) (1951). Reprodução do catálogo da exposição de Matisse (Séligny, 2003, p. 43).

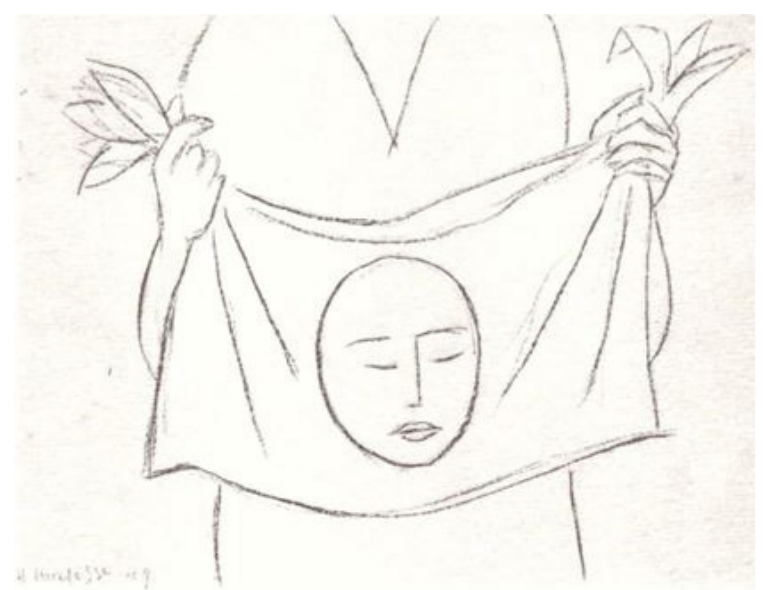

Figura 5: $O$ véu de Verônica. Estudo para a sexta estação da via-crúcis (1949). Reprodução do catálogo da exposição de Matisse (Séligny, 2003, p. 45).

$\mathrm{Na}$ Capela do Rosário, o tópico da combinação da máscara, da face e do transe ganha relevo na representação do rosto de Jesus Cristo no painel da via-crúcis. Como já explicitado, para Matisse o processo de interiorização da temática é articulado com o atravessamento de uma entidade mística. A produção da Santa Face de Cristo consistiria em um dilema particular: o de representar ao mesmo tempo a humanidade da divindade e a força mística que potencialmente o atravessa.

Assim, como destaca Séligny (2003, p. 44), "diante da extrema dificuldade que foi a representação do rosto do Cristo (sexta estação da via-crúcis), é por uma máscara que Matisse escolhe representar o inexprimível”. Se um dos lugares-comuns da arte ocidental é a representação de Cristo e das personagens que se enredam em sua história, para Matisse o empreendimento se apresentou como um desafio. Sua solução apostaria na máscara como síntese da figura humana - única face representada na Capela, explicitadas nas figuras 6 e 7-e, ao mesmo tempo, um ponto de contato e uma abertura para uma dimensão sagrada.

A Via-crúcis consiste em um caso-chave para pensar as combinações entre arte e religião na obra de Matisse pelo modo como condensa procedimentos e disposições que adota na sacralização do seu trabalho.

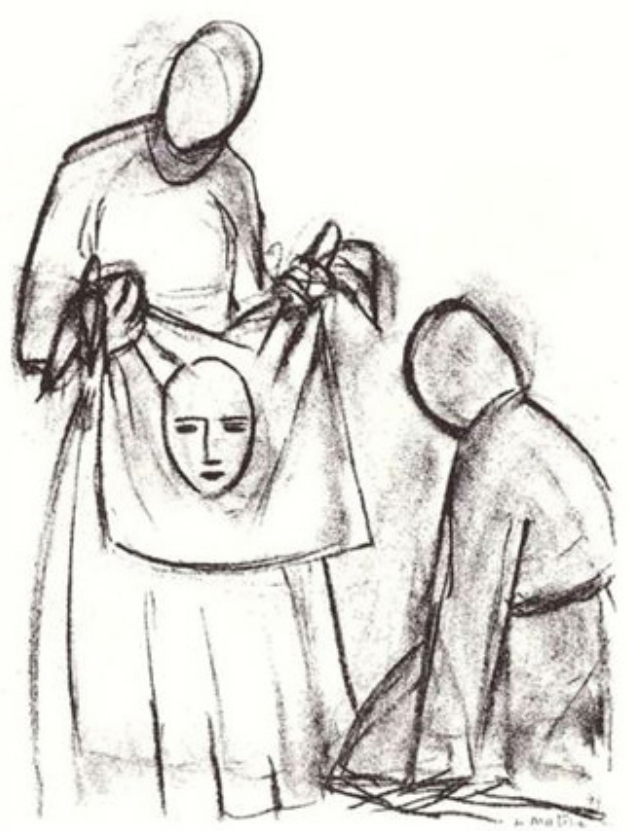

Figura 6: Rascunho para sexta estação da via-crúcis. Reprodução de postal adquirido na boutique da Capela do Rosário. 


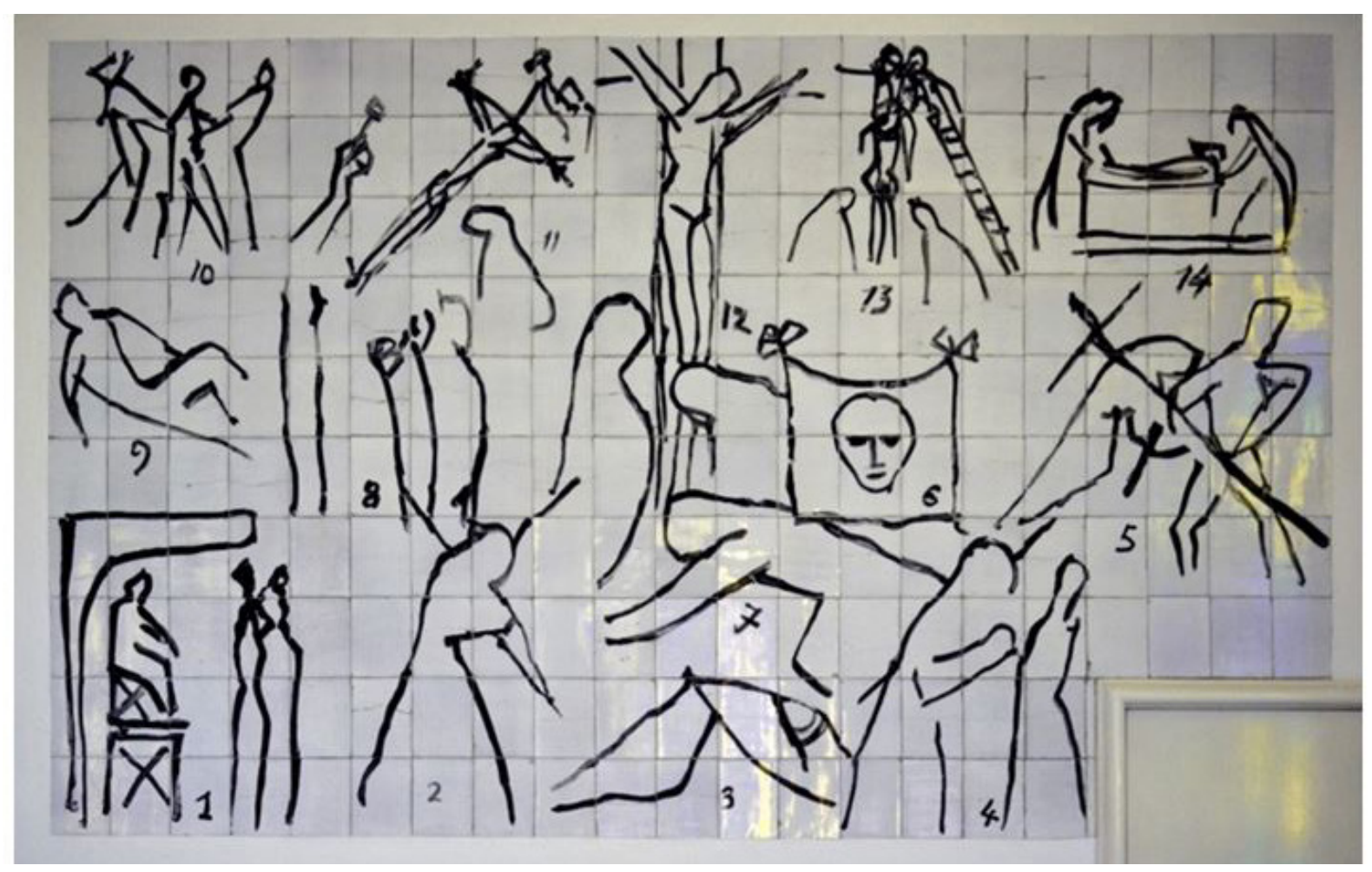

Figura 7: Via-crúcis. Acervo pessoal.

Uma passagem do artigo de Matisse intitulado "A Capela de Vence, resultado de uma vida", publicado no natal de 1951, ajuda a deixar essa reflexão um pouco menos esotérica. Ele explica:

O painel de São Domingos e o da Virgem com o Menino Jesus têm o mesmo espírito decorativo, e sua serenidade possui um caráter de tranquilo recolhimento que lhes é próprio, ao passo que o da Via-crúcis está animado por outro espírito. Ele é tempestuoso. Nele ocorre o encontro do artista com o grande drama de Cristo, que faz com que seu espírito apaixonado transborde pela capela. De início, tendo-o concebido no mesmo espírito dos outros dois painéis, ele havia feito uma procissão com a sequência das cenas. Mas, arrebatado pela emoção desse drama tão profundo, alterou a ordem de sua composição. $\mathrm{O}$ artista se transformou naturalmente no principal ator: em vez de refletir o drama, viveu-o e assim o exprimiu. Ele tem clara consciência do movimento de espírito que essa passagem do sereno ao dramático gera no espectador. Mas a Paixão de Cristo não é o tema mais comovente dos três? (Matisse, 2007, p. 303).

Diferentemente da serenidade que marca as linhas tranquilas dos murais da Virgem com o Menino Jesus e São Domingos, os traços fortes da Via-crúcis demandam que o artista se transfigure em ator para encarnar o drama de Jesus Cristo ${ }^{14}$. Soares descreve o fenômeno do autor que se torna outros personagens como um meio pelo qual ele "impóe metamorfoses à sua identidade e vivencia quase dramaticamente, em seu próprio processo de trabalho, a dualidade marcante [...] do sujeito criador" (1979, p. 130).

Não se trata de representar uma imagem refletida do calvário de Jesus, mas antes de experimentá-lo para ser capaz de atualizá-lo: Matisse torna-se assim o próprio Cristo em seu sofrimento, ao mesmo tempo que espera imprimir essa experiência no painel a ponto de gerar no espectador a emoçáo do recolhimento e da elevação espiritual. O processo de elaboração da Capela do Rosário passa, portanto, pela experiência 
de mediação de uma agência espiritual exterior ao artista, mas que simultaneamente borra as fronteiras entre o artista e a inspiração divina; a arte e o sagrado.

\section{Ambiguidade religiosa e fé na arte}

Após acompanhar o percurso de Matisse até aqui, fica evidente que o artista modula a inflexão religiosa em suas elocuçóes de acordo com seus interlocutores: um vocabulário com referências mais explicitamente sagradas é adotado em comunicaçóes com pessoas religiosas, na mesma medida em que essas referências diminuem (ou desaparecem) em comunicaçóes com artistas e críticos de arte. Um contraponto inflexível à leitura estritamente religiosa de afirmaçóes de Matisse pode ser encontrado nos escritos de sua assistente, Lydia Delectorskaya. Para ela, o emprego da palavra "Deus"

[...] era um clichê, uma réplica maliciosa que Matisse sempre usava para responder aos elogios excessivos, convencionais. [...] A palavra Deus, em si, não tinha peso para Matisse. Ele era e continuou a ser até o final um livre-pensador. "Existe alguma coisa acima de nós. Alguma coisa." E, em seu trabalho, ele achava que, em certos momentos, alguém o substituía. Mas esse alguém não era necessariamente uma divindade; era: "um outro que não eu". [...] Pessoas de diversos lados gostariam de convencer o mundo de que, com a idade, e medo da morte, Matisse havia se convertido ao catolicismo e se ocupado com uma capela para "abrir para si a porta do Paraíso com uma chave de ouro”, como diziam alguns. Não é nada disso. Matisse não tinha medo de morrer, mas medo de sofrer antes de morrer, sofrer fisiologicamente. Pouco antes de sua morte, as irmãs de Vence tinham insistido para que ele "comungasse". Sua recusa foi categórica: "o que eu tinha de fazer, fiz o melhor que pude, todo o resto pouco vale". (Matisse, 2007, p. 321)

O comentário de Delectorskaya está em estreita sintonia com a concepção de "despossessão subjetiva" do indivíduo moderno psicológico, explorada por
Salem (1992). A crise da ordem consciente produzida a partir dos saberes "psis" introduziu um espaço indeterminado e constringente na interioridade do sujeito, mais tarde cunhado de "inconsciente". Domínio irrefletido, produz efeito de uma destituição subjetiva, percebida por sua vez como um perder-se de si mesmo e simultaneamente ser "ocupado por um outro" que muito embora seja eu, só posso acessar através de um outro que não eu, no processo intersubjetivo (como no caso das terapêuticas "psis"). A emergência da psicanálise, entre os outros saberes "psis", fornece um vocabulário científico para as dinâmicas entre o eu e o outro que afloram na produção de artistas modernos como Matisse, enquadramento que renderia uma chave alternativa às interpretaçóes religiosas da mediunidade artística. De leitura alternativa e complementar, é percebido numa interpretação secularizada como leitura exclusiva: os saberes psis operando na construção dos sujeitos (Salem, 1992) subjetivados em uma sociedade moderna desencantada cada vez mais incompatível com sensibilidades religiosas públicas (Asad, 2003).

Para a profissional que trabalhava cotidianamente com o artista, estava clara a incompatibilidade entre a liberdade artística e intelectual de Matisse e uma adesão clássica ao catolicismo via conversão. Esse pensamento atravessa a maior parte das críticas tanto de artistas e críticos de arte, como também de religiosos em relação ao projeto de Matisse em Vence.

$\mathrm{O}$ argumento crítico a uma aproximação entre arte e religião defendido por Delectorskaya é compartilhado por Picasso, o crítico Charbonnier, entre outros interlocutores supracitados e pode ser estendido a boa parte dos envolvidos direta ou indiretamente na produção e consumo da arte moderna, na primeira metade do século XX, estendendo-se à arte contemporânea (Gombrich, 1988; Elkins, 2004; Elkins e Morgan, 2008). Se a autonomização do campo artístico ocorre com o processo de reencantamento da arte (Morgan, 2008), há paralelamente outro, de privatização e abstrativização da religião (Asad, 1993; 2003). Nesse sentido, a modernidade artística efetua uma autossacralização simultânea ao esvaziamento do valor sagrado da religião, que passa a ser um tema ignorado e mesmo atacado pela vanguarda da arte moderna (o que motiva grande parte da crítica dirigida 
ao projeto de Matisse em Vence). ${ }^{15} \mathrm{~A}$ arte passa a desempenhar um papel metafísico e público, o de

salvar a alma de uma nação ou de um povo, purificar o gosto, edificar um público vulgar, transformar a cultura cívica, provocar o iluminismo moral, celebrar o que há de melhor em uma civilização, prover acesso a bens atemporais e universais, revelar verdades de valor transcendental, viabilizar a comunhão com grandes mentes". (Morgan, 2008, p. 16)

Papel a ser estimulado e protegido das ameaças da religiáo, percebida pelo indivíduo subjetivado moderno como dotada de uma natureza sectária, a ser constantemente expurgado dos espaços seculares e restrito ao âmbito da "razão privada". (Asad, 2003, p. 8)

Nesse sentido, o uso de um vocabulário religioso e a ambiguidade da relação de Matisse com a religião podem ser percebidas como estratégias de sacralização da própria arte. Entretanto, essa sacralização não ocorre paralelamente a uma obrigatória dessacralização religiosa, como se dá em grande parte dos trabalhos artísticos do mesmo período. ${ }^{16} \mathrm{~A}$ especificidade da trajetória de Matisse em sua relação com o catolicismo, ao menos no período de produçáo da Capela do Rosário, está na realizaçấo de uma obra de arte moderna na contramáo do imperativo secular de contestação religiosa.

Batizado na infância, e com uma vida inteira longe da prática católica, Matisse não volta a comungar. Na páscoa de 1948, a irmã Jacques-Marie fala com o artista sobre o significado e a importância da comunhão pascal. Em reação, Matisse responde: "Eu não tenho necessidade de me confessar ou de comungar". Em seguida, ele completa: "Eu refleti para saber se poderia me confessar 'para te agradar'. E não, eu não posso, mesmo isso". (Jacques-Marie, 1992, p. 85)

Tal opção, entretanto, não dissipa ou deslegitima as aproximaçōes com o catolicismo experimentadas ao longo de quatro anos de produção da Capela do Rosário. A abertura intelectual aos experimentalismos estéticos é um pilar do fazer artístico de Matisse, que o mantém fortemente ancorado na modernidade.
Ao mesmo tempo, a relação que entretém com a religiâo católica também consiste em um arranjo moderno, que flerta com o catolicismo, atravessado pela ambiguidade dos sentimentos de atração e repulsão que seus ritos e dogmas o suscitam.

\section{Consideraçóes finais}

A capela do Rosário é uma das últimas obras significativas da trajetória artística de Matisse. Ao longo de sua vida, o artista elabora uma técnica de trabalho apoiada no despojamento, condensação e simplificação dos seus traços; e no uso de cores densas e compactas, sem diluiçôes. Tal singularidade se conecta com um movimento mais geral de elaboraçáo de um dispositivo de sensibilidade (Dias Duarte, 1999) da arte moderna, focado nos experimentalismos, na imanência da vida humana (sua corporalidade) e no mergulho na interioridade e no inconsciente. Ao mergulhar em si, investigando suas habilidades e limites, bem como seus interesses, verdades e sua originalidade, Matisse segue um caminho muito semelhante ao de diversos artistas ancorados na "singularidade apoiada na vocação", proposta por Heinich (2005). Entretanto, se, como indica Reinheimer na linha de Heinich, a singularidade do artista vocacionado gera um "produto final [como] resultado da convulsão do gênio (oposta à lenta maturação da técnica), somente para os eleitos e quase patológica" (Reinheimer, 2008, p. 184), Matisse jamais substitui a labuta artesanal pelo dom.

Embora se sentisse atravessado (por um "sopro divino", por "um outro que náo eu"), Matisse luta contra a ausência de uma vocação toda a sua vida; ele sente que não fora dotado do dom que outros artistas receberam e que seu trabalho artístico é resultado de muito esforço para compensar essa ausência. Sua afirmação como artista do prazer e do hedonismo ocorre tardiamente, e, ainda assim, nunca deixa de receber críticas duras sobre sua falta de talento para a representação realista, seus retratos "monstruosos", seus traços "deformados" e infantis. Se "a falta de facilidade natural [...] fizera de sua carreira um esforço interminável" (Spurling, 2012, p. 511), o trabalho constante para desenvolver um estilo pessoal se torna 
um imperativo de sobrevivência, em um contexto artístico em que a originalidade é valorizada.

O trabalho de Matisse em Vence é uma derradeira tentativa de sacralizaçáo institucional de sua obra, com a realização de um trabalho religioso. Nesse sentido, seu projeto se aproximaria a um "estilo tardio" harmônico, que, como propóe Said (2009), coroaria o final da vida de um artista com uma obra síntese afinada com o percurso desenvolvido até então. Porém, é possível fazer uma leitura alternativa. Além da ausência de uma consagração artística consolidada (até aquele momento), seu empreendimento na Capela não segue uma linha de continuidade em relação ao seu trabalho anterior, ao menos em duas frentes. De saída, é a primeira vez que Matisse realiza um projeto religioso, o que, como vimos, aparece muito mais como um empecilho do que como vantagem para consagração no universo da arte moderna. Em seguida, se é factível identificar os vitrais, painéis de São Domingos e da Virgem, entre outros elementos, com sua obra mais geral, e seus estudos sobre cores e retratos em particular, o painel da Via-crúcis é completamente inovador em relação ao seu estilo desenvolvido até então. Sua agressividade, violência e força ${ }^{17}$ contrastam diretamente com a "economia visual do prazer" (Schama, 2014) que definiria a obra de Matisse, segundo boa parte dos críticos, os mesmos que ignoram completamente a Capela do Rosário em suas consideraçóes. ${ }^{18}$

O "estilo tardio" de Matisse em Vence transborda de um sentido estritamente autossacralizante institucional, para outro marcado pela "intransigência, dificuldade e contradição em aberto” (Said, 2009, p. 27), paradoxalmente, apoiando-se em uma imersão no repertório religioso. O paradoxo está em se aproximar da religião para transgredir os próprios padróes estéticos lapidados dentro dos cânones da arte moderna. Ao lançar mão de uma série de procedimentos e disposiçóes que combinam os repertórios artístico e católico, o artista aciona o potencial criativo da associação: seu modo de fazer arte é atravessado pela religião; a edificação religiosa é, ao mesmo tempo, uma obra de arte.

Um elemento chave que condensa essa conjunção é o termo "espírito". Ele é utilizado com frequência por Matisse para se referir ao seu trabalho, principalmente em Vence, mas não apenas, como aparece ao longo do texto. Essa recorrência ajuda a dimensionar o sentido da mediação entre arte e religião que sua obra atualiza. Para além de um significado circunscrito ao "espiritualismo", ou àquilo que diz respeito à esfera religiosa, a palavra francesa "esprit" contém uma pluralidade semântica em sintonia com sua trajetória nos debates filosóficos. Lalande (1997) repertoria alguns dos sentidos predominantes que a ideia do espírito adquiriu: o princípio da vida, a alma individual, a realidade pensante, a razáo humana, a ideia central. Se o espírito se construiu principalmente em oposição a outras ideias, tais como à de matéria, de natureza, de carne, o termo é explorado por Matisse em sua ambiguidade, ora no sentido iluminista do espírito/razão, ora no sentido místico espírito/alma, abrangendo a sensibilidade e o corpo. Outra chave de leitura possível para essa ambiguidade é identificar nela a tentativa de Matisse de explorar o amplo espectro dos significados do espírito, assim como o máximo rendimento das conexóes entre o religioso e artístico; o sagrado e a "fresca beleza do mundo".

Depois desse percurso, a própria ambiguidade da postura do artista diante dos questionamentos sobre sua religiosidade ganha outras cores, tornando-se menos uma questão de branco ou preto e mais uma cartela de tons nuançados. Matisse oscilava entre aproximaçóes e distanciamentos do vocabulário e das práticas institucionais católicas, principalmente de acordo com seu interlocutor, mas não se tratava apenas de uma estratégia para falar religiosamente aos católicos e tecnicamente aos artistas.

Ao longo do artigo, explorei o modo como a metodologia de trabalho artístico de Matisse envolve procedimentos e disposiçóes religiosas. O ponto constante é a regular composição entre os vocabulários e práticas religiosas e artísticas, explorando a máxima potência dessa parceria, que se estende à própria vida de Matisse. Em sua prática, a mistura potencializa sua obra, na contramão de um princípio secular de separaçáo entre as esferas da religião e da arte, defendida por artistas de vanguarda e por segmentos religiosos. Consequentemente, o caso da construção da capela lança uma luz sobre os termos dessa separação, e suas tensões, a partir de uma situação concreta. Nesse sentido, a ambiguidade caracteriza também o modo 
como a potência da combinação sacraliza seu trabalho sem, entretanto, substituir totalmente a sacralização religiosa, mas trabalhando com ela, num estado de espirito próximo da prece. Os procedimentos artísticos de experimentação, imersão, atravessamento, transe, jogo, mergulho no tema, na interioridade da figura humana e sagrada, ao mesmo tempo que criam as formas, faces, máscaras e todas as materialidades envolvidas no projeto, repercutem na vida do artista, marcada por uma continuidade em relação à sua obra. A cada movimento, manipulando cores e formas encantadas, o artista se torna o monge, o mago, o médium devotado a elevar, clarear, evadir e arrastar os sentidos de quem entra em contato com sua obra. Em sua prática artística na Capela, Matisse atualiza a religiosidade como modo de operação, uma performance para alcançar uma dimensão espiritual em sua obra.

\section{Agradecimentos}

$\mathrm{O}$ assunto deste artigo faz parte da minha tese de doutorado (Oliveira, 2014). Agradeço aos pareceristas da $R B C S$ e a Edilson Pereira, Emerson Giumbelli, Lilian Gomes, Luiz Augusto Campos e Milly Lacombe pela atenção dada ao texto.

\section{Notas}

1 São pessoais todas as traduçóes de obras em língua estrangeira em citaçóes deste artigo.

2 Sublinho o pioneirismo do projeto da Pampulha em relação ao contexto do movimento europeu de modernizaçáo de arte sacra. Construída entre 1943 e 46, a Igrejinha antecede em dois anos o início do projeto em Vence e é contemporânea à construção da Igreja de Notre Dame de Toute Grâce em Assy, na região dos Alpes franceses, inaugurada em 1946 e decorada por diversos artistas modernos, tais como Braque, Chagal, Matisse, entre outros, considerada marco inicial do movimento (Caussé, 2010; Baptista, 2002).

3 A pesquisa de campo na França aconteceu entre fevereiro de 2011 e março de 2012, período no qual realizei meu doutorado sanduíche na EPHE, residindo em Paris e com visitas a Vence. Nessas ocasióes, eu me hospedava no Lar Lacordaire anexo à capela e convivia com as irmãs e o padre residentes, assim como com os visitantes da capela e frequentadores das missas. Além disso, tinha acesso à biblioteca da capela e a documentos sobre sua construção. Em Vence, pesquisei ainda em outras bibliotecas e arquivos públicos, e fiz o mesmo em Paris. Mais informaçôes sobre o desenho metodológico da pesquisa em Oliveira (2014).

4 O material utilizado para a análise conta com matérias de jornais de circulaçáo internacional, nacional e regional, revistas de variedades e especializadas (em arte, arquitetura, religião etc.), documentos e correspondências privadas e públicas, biografias das personagens envolvidas no debate, entre outras fontes. Dentre elas, destaca-se a obra La Chapelle de Vence: journal d'une création (1993), organizado por M. Billot, que consiste em um compêndio de todas as notas, atas das reunióes e cartas trocadas entre Matisse, frei Rayssiguier e outras pessoas envolvidas no período de execução da capela. Para uma contextualização pormenorizada da construção do corpus de dados, ver Oliveira (2014).

5 Segundo o historiador da arte Alfred Barr (1951, p. 387), "A pequena capela foi tomada por uma multidão muito grande para caber nela e todo o maquinário moderno de divulgação aumentou a excitação - microfones de rádio, câmeras de vídeo, repórteres, e fotógrafos de imprensa, entre os últimos, afortunadamente, o sagaz Cartier-Bresson".

6 O crítico é Louis Vauxcelles ("Le Salon d'Automne", Gil Blas, 17 out. 1905). De acordo com a biógrafa de Matisse, Hilary Spurling, o apelido fora incorporado por Matisse a despeito de seu sentido originalmente depreciativo: "Para ser sincero, foi admirável. O termo fauve dificilmente poderia ser mais adequado ao nosso estado de espírito", teria declarado o artista (Spurling, 2012, p. 138).

7 Matisse era ainda bebê quando a Guerra Franco-Prussiana (1870-1871) devastou a região da cidade de Cateau-Cambrésis onde nascera e vivia sua família. Na Primeira Grande Guerra, Matisse então com 45 anos é impedido de se alistar, e o ministro dos trabalhos públicos lhe teria sugerido que a melhor forma de servir ao seu país seria continuar pintando (Escholier, 1956). Na Segunda Guerra Mundial, Matisse está com 70 anos, muito doente, um mal no intestino o leva a realizar uma cirurgia de emergência em 1941, à qual sobrevive com inúmeras restriçóes físicas, sendo obrigado a trabalhar no seu leito por longos períodos. Durante a guerra, sua esposa Amélie Matisse e sua filha Marguerite Duthuit são presas por envolvimento na Resistência.

8 Matisse viajou para muitas regióes diferentes da França, inicialmente para o norte (Bretanha) e em seguida em direção ao sul, onde a luminosidade era abundante. Sua estadia preferida era Colliure, onde pintou diversas telas; em seguida, passou a ser a região da Cote D'Azur, 
principalmente a cidade de Nice, onde viveu os últimos anos de vida, com períodos de recolhimento na vizinha Vence. $\mathrm{O}$ artista também viajou para outros países: Inglaterra, Argélia, Itália, Alemanha, Espanha, Rússia, Marrocos, Taiti, Estados Unidos. Todos esses destinos desempenharam um papel determinante no desenvolvimento do trabalho do artista, tanto do ponto de vista dos temas, paisagens, figuras, quanto das técnicas de uso de cor, iluminação (Matisse, 2007; Wright, 2004).

9 Matisse e a irmã Jacques-Marie se conheceram em 1942 quando o artista precisara de uma acompanhante para ajudá-lo com as suas crises de dores abdominais noturnas. A então jovem estudante de enfermagem Monique Bourgeois passa a ser cuidadora e, em seguida, modelo e amiga de Matisse. Eles convivem cotidianamente até que no ano seguinte Monique segue para uma viagem ao interior do país dedicada a atividades religiosas e Matisse, em meio aos bombardeios a Nice, onde morava há alguns anos, decide se refugiar a alguns quilômetros, na cidade medieval alpina de Vence. Com o fim da guerra, a já ordenada irmá Jacques-Marie passa a viver no Lar Lacordaire, hospedaria e casa de repouso das irmás dominicanas de Vence, reencontrando Matisse, que morava a poucos metros dali. Ambos voltam a conviver e Matisse toma conhecimento do sonho da irmã de reconstruir a capela do Lar Lacordaire, destruída num incêndio. Poucos meses depois e com a parceria do frade Rayssiguier, que nutria um grande interesse por arquitetura e arte modernas, Matisse inicia seu plano de construir uma obra de arte total, desde sua concepçáo espacial, passando pela decoração, objetos litúrgicos, até as vestimentas sacerdotais. $\mathrm{O}$ artista assumiu até mesmo a responsabilidade pelo financiamento da edificação, realizando exposiçóes e vendas de suas obras para levantar recursos para sua construção (Matisse et al., 1993). Seu empreendimento encontrou resistência entre freiras dominicanas de Vence e entre outros religiosos da hierarquia católica, assim como contou com alguns simpatizantes. Discuto pormenorizadamente os detalhes da negociação em torno da produção da capela em Oliveira (2014).

10 Sobre a Capela do Rosário, Elkins (2004, p. 14) afirmou: "deve ser o único exemplo de pintura do século XX que é, ao mesmo tempo, uma obra religiosa consagrada e [feita por] um membro conceituado do modernismo canônico”.

11 Obra devocional publicada no século XV, de autoria de Tomás de Kempis. De acordo com o historiador Rodrigo Monteiro (2007, p. 135), ela "resume o ideal de devotamento, pobreza e piedade na Europa [Medieval]".
12 Dupla incoerência, considerando que a prática religiosa em questão é característica de movimentos religiosos protestantes.

13 Séligny utiliza a palavra esquimó entre aspas para se referir ao modo como o artista e a obra foram organizados, mas ao longo do texto dá preferência ao termo inuíte.

14 Destaque-se que, de acordo com as notas de Rayssiguier, no segundo encontro entre ele e Matisse para discutir o projeto de construção da capela, o religioso teria apresentado ideias para as composiçóes da Virgem Maria e de São Domingos, fundador da ordem dominicana, e o artista teria proposto a Via-Crúcis (Matisse et al., 1993, pp. 38-39). Somente nas "notas preparatórias do frade Rayssiguier”, redigida poucos meses depois, é explicitada a invocação da padroeira da Ordem Dominicana, Nossa Senhora do Rosário (p. 41).

15 No quarto capítulo da minha tese, analiso a recepção controversa da Capela do Rosário tanto entre artistas e críticos, quanto entre religiosos leigos e membros da hierarquia católica (Oliveira, 2014).

16 Algumas exceçôes ficaram conhecidas como movimento de modernização da arte sacra, mencionado na introdução deste artigo, e foram analisadas por Gamboni (1997), Caussé (2010), Baptista (2002), Oliveira (2014), entre outros.

17 De acordo com a biógrafa de Matisse, "único aspecto da capela que contou com a aprovação irrestrita de Picasso" (Spurling, 2012, p. 525).

18 É grande a quantidade de artigos e textos sobre a obra de Matisse que analisam sua trajetória ignorando ou transpondo o tópico da Capela do Rosário, referindo-se aos trabalhos posteriores. Um exemplo é o artigo de Schama (2014) que, embora pretenda analisar o impacto do envelhecimento na arte de Matisse e Picasso, sequer menciona a capela.

\section{BIBLIOGRAFIA}

ASAD, Talal. (1993), Genealogies of religion. Discipline and reasons of power in christianity and islam. Baltimore, The Johns Hopkins University Press. ASAD, Talal. (2003), Formations of the Secular: Christianity, Islam, Modernity. Stanford: Stanford University Press.

BAPTISTA, Anna Paola. (2002), O Eterno ao Moderno: arte sacra católica no Brasil - anos 4050. Tese de doutorado em História Social. Rio de Janeiro, UFRJ. 
BARR, Alfred H. (1951), Matisse: his art and his public. New York: Museum of Modern Art.

BARRY, Joseph. (1948), "Matisse turns to religious art". The New York Times, $26 \mathrm{dez}$.

BIRMAN, Patricia. (2005), "Transas e transes: sexo, gênero nos cultos afro-brasileiros, um sobrevoo". Estudos Feministas, 13(2): 403-413.

BRASIL, Ubiratan. (2013), "Adélia Prado retorna à poesia com 'Miserere"'. O Estado de S. Paulo, $6 \mathrm{dez}$. Disponível em: <https://cultura.estadao. com.br/noticias/geral,adelia-prado-retorna-apoesia-com-miserere,1105245>. Acesso em: 7 dez. 2013.

CAILLOIS, Roger. (1990 [1958]), Os jogos e os homens. A máscara e a vertigem. Lisboa, Cotovia.

CAUSSÉ, Françoise. (2010), La revue 'L'Art Sacré: le débat en France sur l'art et la religion (19451954). Paris, Cerf.

CHARBONNIER, Georges. (1951), Entrevista com Henri Matisse. (áudio) 12 jan. (21 min 45s). Disponível em: <https://www.ina.fr/video/ PHD89017431>. Acesso em: 19 nov. 2013.

DIAS DUARTE, Luiz Fernando. (1999), “O império dos sentidos: sensibilidade, sensualidade e sexualidade na cultura ocidental moderna”, in M. L. Heilborn (org.), Sexualidade. O olhar das ciências sociais, Rio de Janeiro, Zahar.

DIAS DUARTE, Luiz Fernando \& GIUMBELLI, Emerson. (1995), "As concepçóes cristã e moderna da pessoa: paradoxos de uma continuidade". Anuário Antropológico, 93. Rio de Janeiro, Tempo Brasileiro.

ELKINS, James. (2004), On the strange place of religion in contemporary art. New York/London, Routledge.

ELKINS, James \& MORGAN, David. (2008), Reenchantment. The Art Seminar, v. 7. New York/ London, Routledge.

ESCHOLIER, Raymond. (1956), Matisse ce vivant. Paris, Fayard.

GAMBONI, Dario. (1997), The destruction of art: iconoclasm and vandalism since the French Revolution. London, Reaktion Books.
GIUMBELLI, Emerson. (2002), O fim da religião: dilemas da liberdade religiosa no Brasile na França. São Paulo, Attar/Pronex.

GOLDMAN, Marcio. (1984), A possessão e a construção ritual da pessoa no candomblé. Dissertação de mestrado em Antropologia Social, Rio de Janeiro, MN/UFRJ.

GOMBRICH, Ernst H. (1988), A história da arte. Rio de Janeiro, Editora Guanabara.

HEINICH, Nathalie. (2005), L'élite artiste. Excellence et singularité en régime démocratique. Paris, Gallimard.

JACQUES-MARIE. (1992), Henri Matisse, La Chapelle de Vence. Nice, Grégoire.

LALANDE, Andre. (1997 [1923]), Vocabulaire technique et critique de la Philosophie. 4. ed. Paris, PUF.

LATOUR, Bruno. (1994), Jamais fomos modernos. Rio de Janeiro, Editora 34.

LATOUR, Bruno. (2005), Reassembling de social: an introduction to actor-network-theory. Oxford, Oxford University Press.

LE BRETON, David. (1995), "Le visage et le sacré: quelques jalons d'analyse”. Religiologiques, 12: 49-64.

MATISSE, Henri. (2005 [1972]), Écrits et propos sur l'art. Paris, Hermann éditeurs.

MATISSE, Henri. (2007 [1972]), Escritos e reflexões sobre arte. Tradução de Denise Bottman. São Paulo, Cosac Naify.

MATISSE, Henri. (2010), Jazz et autres éditions. Bouches-du-Rhône/Aix-en-Provence: Galerie d'art du Conseil General des Bouches-du-RhôneAix-en-Provence.

MATISSE, Henri; COUTURIER, M. A. \& RAYSSIGUIER, L. B. (1993), La Chapelle de Vence: journal d'une création. Paris/Genebra, Cerf/Menil Fundation.

MONTEIRO, Rodrigo Bentes. (2007), "As reformas religiosas na Europa moderna: notas para um debate historiográfico". Varia historia, 23 (37): 130-150.

MONTERO, Paula. (2016). “'Religiōes públicas' ou religiōes na esfera pública? Para uma crítica ao 
conceito de campo religioso de Pierre Bourdieu". Religião \& Sociedade, 36 (1): 128-150.

MORGAN, David. (2008), "Enchantment, disenchantment, re-enchantment", in ReEnchantment, The Art Seminar, v. 7. New York/ London, Routledge.

OLIVEIRA, Paola Lins de. (2014), Oferendas modernas: religiäo, arte e política na construção de obras-lugares no Brasil e na França. Tese de doutorado em Antropologia Cultural, Rio de Janeiro, IFCS-UFRJ.

OLIVEIRA, Paola Lins de. (2018), "Religião, arte e política na controvérsia pública da Igrejinha da Pampulha”. Revista de Antropologia, 61 (1): 241-268.

RABELO, Miriam C. (2008), "A possessão como prática: esboço de uma reflexão fenomenológica”. Mana, 14 (1): 87-117.

RANQUETAT, Cesar. (2014), "A imagem de Cristo nos parlamentos". Religiāo \& Sociedade, 34 (1): 94-121.

REINHEIMER, Patricia. (2008), A singularidade como regime de grandeza: nação e indivíduo como valores no discurso artístico brasileiro. Tese de doutorado em Antropologia Social, Rio de Janeiro, MN/UFRJ.

SAID, Edward. (2009), Estilo tardio. São Paulo, Companhia das Letras.
SALEM, Tânia. (1992), "A 'despossessão subjetiva’: dos paradoxos do individualismo". Revista Brasileira de Ciências Sociais (RBCS), 7 (18): s.p.

SCHAMA, Simon. (2014), "How Matisse and Picasso turned old age into art". Financial Times, 4 abr. 2014. (Visual Arts). Disponível em <http:// www.ft.com/intl/cms/s/2/59192b0c-b994-11e3b74f-00144feabdc0.html\#slide0>. Acesso em: 5 jan. 2015.

SÉLIGNY, Marie-Thérèse. (2003), "Une fête en Cimmérie de l'autoportrait au masque", in Un fête en Cimmérie: représentation du visage dans l'oeuvre de Matisse (catálogo da exposiçāo realizada no Musée Matisse, Nice, 25 de junho a 4 de setembro de 2003). Nice, Réunion des Musées Nationaux/Mairie de Nice.

SOARES, Luiz Eduardo. (1979), "O autor e seu duplo: a psicografia e as proezas do simulacro". Religião e Sociedade, 4: 121-140.

SPURLING, Hilary. (2012), Matisse: uma vida. São Paulo, Cosac Naify.

STOLLER, Paul. (1997), Sensuous scholarship. Philadelphia, University of Pennsylvania Press.

WEBER, Max. (1982), "Rejeiçôes religiosas no mundo e suas direçôes”, in H. H. Gerth e C. Wright Mills (orgs.), Ensaios de sociologia, Rio de Janeiro, LTC. WRIGHT, Alastair. (2004), Matisse and the subject of Modernism. Princeton/Oxford, Princeton University Press. 


\section{MATISSE E A RELIGIÁO DA ARTE}

\section{Paola Lins de Oliveira}

Palavras-chave: Sacralização da arte; Religião; Vanguarda; Secularização; Matisse.

Ao se aproximar dos oitenta anos de idade, o artista plástico Henri Matisse embarca com um frade dominicano no projeto de construçáo de uma capela na região francesa dos Alpes Marítimos. A empreitada gera resistências entre diversos artistas e religiosos, preocupados respectivamente com a contaminação da arte de vanguarda pelo conservadorismo católico e com a profanação modernista da arte sacra. Neste artigo, analiso a construção da Capela do Rosário (1947-1951) como caso-chave para explorar os efeitos do consórcio entre arte e religião promovido por Matisse em dois planos simultâneos e complementares. No primeiro, investigo como a composição entre os vocabulários e práticas religiosas e artísticas potencializa a construção da obra de Matisse, gerando repercussóes na própria vida do artista. No segundo, apuro como essa associação produz um tensionamento do princípio moderno e secular de separaçáo entre as esferas da arte e da religião, iluminando os termos dessa separação. O percurso realizado em pesquisa de campo na França e análise de diferentes fontes documentais revela que a religiáo (seja ela o catolicismo, um espiritualismo difuso ou outras manifestaçóes sagradas) adquire o estatuto de procedimento articulador através do qual o artista constrói sua obra e através dela a si mesmo.

\section{MATISSE AND THE RELIGION OF ART}

\section{Paola Lins de Oliveira}

Keywords: Art sacralization; Religion; Avant-garde; Secularization; Matisse.

When approaching eighty years of age, artist Henri Matisse embarked on a project to build a chapel in the French region of the Alpes Maritimes with a Dominican friar. The undertaking generates resistance among various artists and religious individuals, concerned with the contamination of avant-garde art by Catholic conservatism and the modernist desecration of sacred art, respectively. In this paper, I analyze the construction of the Chapel of the Rosary (1947-1951) as a key case to explore the effects of the consortium between art and religion promoted by Matisse on two simultaneous and complementary levels. In the first, I investigate how the composition between religious and artistic vocabularies and practices enhances the construction of Matisse's work, generating repercussions in the artist's own life. In the second, I examine how this association produces a tension between the modern and secular principle of separation between the art and religion spheres, illuminating the terms of this separation. The path taken through field research in France and the analysis of different documentary sources reveals that religion (be it Catholicism, diffuse spiritualism or other sacred manifestations) acquires the status of an articulating procedure throughout which the artist constructs his work, and, through it, himself.

\section{MATISSE ET LA RELIGION DE L'ART}

\section{Paola Lins de Oliveira}

Mots-clés: sacralisation de l'art; religion; avant-garde; laïcité; Matisse.

À près de quatre-vingts ans, l'artiste Henri Matisse se lance avec un frère dominicain dans le projet de construction d'une chapelle dans les Alpes-Maritimes, la chapelle du Rosaire. Néanmoins, l'entreprise se heurte à plusieurs résistances: des artistes s'inquiètent d'une contamination de l'art d'avant-garde par le conservatisme catholique, tandis que certains religieux redoutent une profanation moderniste de l'art sacré. Ce travail analyse la construction de la chapelle (1947-1951) pour mettre en lumière les effets du rapprochement entre art et religion promu par Matisse à deux niveaux simultanés et complémentaires. Dans un premier temps, il est montré que la composition opérée entre les pratiques et les vocabulaires religieux et artistiques accroissent la construction de l'œuvre de Matisse, avec y compris des répercussions sur la vie de l'artiste. Dans un deuxième temps, l'analyse permet de mieux comprendre pourquoi une telle association contrarie le principe moderne et laïque de séparation entre les versants artistique et religieux. L'enquête de terrain en France et l'analyse de différentes sources documentaires révèlent que la religion (que ce soit le catholicisme, le spiritisme diffus ou d'autres manifestations sacrées) articule la construction de l'œuvre et la construction personnelle de l'artiste. 